\title{
PEMANFAATAN GREEN ROOF SEBAGAI MEDIA FILTER AIR HUJAN DI KOTA PONTIANAK
}

\author{
Uria Karlena Sely Sakong \\ Program Studi Teknik Lingkungan, Universitas Tanjungpura, Pontianak \\ Email: ft.sely_sakong@yahoo.com
}

\begin{abstract}
ABSTRAK
Penelitian ini bertujuan untuk mempelajari pengaruh green roof terhadap kualitas air hujan di Kota Pontianak. Pengaruh tersebut dipelajari dengan cara membandingkan antara kualitas air hujan yang melewati green roof dengan kualitas air yang tidak melewati green roof. Penelitian diawali dengan merancang dan membuat model green roof. Pengambilan sampel dilakukan sebanyak empat kali dan diuji di laboratorium terhadap parameter $\mathrm{pH}$, kekeruhan, $\mathrm{Pb}$ terlarut dan E.Coli. Metode analisa menggunakan metode analisa statistika anova satu jalur (one way-anova).

Hasil yang diperoleh dari penelitian ini adalah rata-rata $\mathrm{pH}$ air hujan lewat green roof sebesar 6,29 sedangkan air hujan yang tidak lewat green roof sebesar 5,29 dan 5,33. Rata-rata kekeruhan air hujan yang lewat green roof sebesar 149,75 NTU sedangkan rata-rata air hujan yang tidak melewati atap hijau sebesar 1,235 NTU dan 1,845 NTU. Rata-rata Pb terlarut pada air hujan yang lewat green roof dan tidak lewat green roof sebesar 0,0161 ppm, 0,0144 ppm, dan 0,0169 ppm. Indentifikasi bakteri E.Coli pada air hujan lewat green roof negatif. Sehingga dapat disimpulkan bahwa, atap hijau memberikan pengaruh signifikan terhadap parameter $\mathrm{pH}$ dan kekeruhan, namun tidak pada parameter $\mathrm{Pb}$ terlarut dan E.Coli.
\end{abstract}

Kata kunci: Green roof, Kualitas Air Hujan, Kota Pontianak

\begin{abstract}
This research aims to study the effect of the green roof rain water quality in Pontianak. The effect was studied by comparing the quality of rain water through green roof with water quality that does not pass through the green roof. The research begins with designing and building a model green roof. Sampling was conducted four times and tested in the laboratory against the parameters $\mathrm{pH}$, turbidity, dissolved $\mathrm{Pb}$ and E.Coli. The method of analysis used one-way ANOVA statistical analysis.

The results obtained from this study is the average $\mathrm{pH}$ of rain water through the green roof at 6,29 while the rain water does not pass the green roof at 5,29 and 5,33. Average turbidity of rain water through the green roof of 149,75 NTU while the average rain water does not pass through the green roof at 1,235 and 1,845 NTU. Average $\mathrm{Pb}$ dissolved in rainwater passing through the green roof and rain water that does not pass through the green roof at 0,0161 ppm, 0,0144 ppm, and 0,0169 ppm. Identification of $E$. coli in rain water through green roof was negative. It can be concluded that green roof provide significant influence on parameters of $\mathrm{pH}$ and turbidity, but not on the parameters of dissolved $\mathrm{Pb}$ and E.Coli.
\end{abstract}

Keywords: Green roof, Rain Water Quality, The City Of Pontianak

\section{Pendahuluan}

Pembangunan ruang selama ini dilakukan berorientasi pada perluasan secara horizontal. Akibatnya, akan semakin mengurangi Ruang Terbuka Hijau (RTH) yang ada. Namun, beberapa tahun belakangan ini arah pembangunan sudah mulai berorientasi secara vertikal. Hal ini disebabkan oleh lahan yang semakin menyempit sehingga harga lahan semakin meningkat. Sedangkan, kebutuhan masyarakat akan lahan semakin beragam. Sama halnya dengan Kota Pontianak, bangunan-bangunan yang ada seperti hotel, perkantoran, pertokoan dan bangunan bertingkat lainnya dibangun hampir menghabiskan lahan yang ada tanpa menyisakan lahan untuk Ruang Terbuka Hijau (RTH).

Usaha membangun sebuah kota yang sustainable berarti pula usaha untuk mencari bentuk-bentuk baru dari penghijauan kota, dimana penghijauan dilakukan tidak hanya dalam arah horizontal belaka, 
melainkan juga ke arah vertikal. Salah satunya adalah dengan menggunakan taman atap atau atap hijau (green roof). Keberadaan taman atap, khususnya di kota-kota besar (metropolis) memiliki peran penting seperti halnya ruang hijau lainnya. Ancaman terhadap eksistensi Ruang Terbuka Hijau (RTH) akibat pembangunan infrastruktur-infrastruktur kota dapat diimbangi atau dikompensasi dengan mengembangkan atap hijau (Arisanti, 2005).

Pada umumnya manfaat atap hijau adalah mengurangi tingkat polusi udara, menurunkan suhu udara, konservasi air, mengurangi polusi suara/kebisingan, menampilkan keindahan pada aspek bangunan (estetika), dan meningkatkan kenaekaragaman hayati kota. Fungsi atap hijau sebagai penyaring air hujan belum dimanfaatkan. Apalagi di daerah seperti Kalimantan Barat yang memiliki karakteristik unik yakni hujan merata sepanjang tahun, dan masyarakatnya masih menggunakan air hujan untuk dikonsumsi.

Kebiasaan masyarakat Kota Pontianak yang menggunakan air hujan sebagai air minum sudah berlangsung lama hingga sampai saat ini masih terus berjalan, selain itu juga air hujan digunakan oleh masyarakat Kota Pontianak sebagai cadangan air bersih untuk digunakan pada musim kemarau. Namun ketika musim kemarau datang, air hujan yang turun akan menurun kualitasnya. Penurunan kualitas umumnya terjadi pada hujan selama musim kemarau dan hujan di awal musim penghujan. Hal ini dikarenakan masyarakat yang berada di sekitar wilayah Kota Pontianak memanfaatkan kondisi saat kemarau untuk membuka lahan baru untuk bercocok tanam dan berkebun dengan cara membakar habis lahan yang akan digunakan, sehingga partikulat dari pembakaran lahan tersebut terbawa oleh angin menuju Kota Pontianak yang berdampak pada penurunan kualitas air hujan di Kota Pontianak.

Berdasarkan permasalahan di atas, maka muncullah gagasan untuk mempelajari pengaruh green roof sebagai media penyaring air hujan di Kota Pontianak. Pengaruh green roof sebagai media penyaring akan dipelajari dengan cara menguji kualitas air hujan yang melalui green roof dan kemudian membandingkannya dengan kualitas air hujan yang tidak melalui green roof (kualitas air ambient).

\section{Metode Penelitian}

Penelitian dilakukan dari bulan April 2012 - Desember 2012, dimana pengambilan sampel dilakukan pada Bulan Nopember 2012 - Bulan Desember 2012. Untuk melihat pengaruh green roof terhadap air hujan yang melewatinya, maka metode analisa yang digunakan meliputi analisa curah hujan, dimana data curah hujan yang digunakan adalah data curah hujan harian dan data tersebut dianalisa menggunakan analisa time trend dengan data rata-rata bergerak 5 tahunan (5-year moving average) untuk menunjukan perubahan time trend yang diuji lagi dengan membuat trend line pada grafik curah hujan tahunan, yaitu dengan membuat garis lurus yang mewakili grafik jumlah curah hujan tahunan yang disebut trend line. Kemudian dilakukan pengambilan dan pengujian sampel di laboratorium pada parameter $\mathrm{pH}$, kekeruhan, $\mathrm{Pb}$ terlarut dan E. Coli. Adapun sampel yang diambil terbagi menjadi 3 buah sampel yaitu, sampel air hujan yang tidak melewati green roof pada pengambilan pertama, sampel air hujan yang tidak melewati green roof pada pengambilan kedua dan sampel air hujan yang melewati green roof. Pengambilan sampel dilakukan sebanyak 4 kali.

Berikut ini gambar model green roof yang digunakan dalam penelitian, dimana green roof tersebut diletakkan di halaman depan Laboratorium Teknik Lingkungan dan Laboratorium Teknik Lingkungan Fakultas Teknik, Universitas Tanjungpura. Tampak model green roof dapat dilihat pada Gambar 2.1 di bawah ini. 


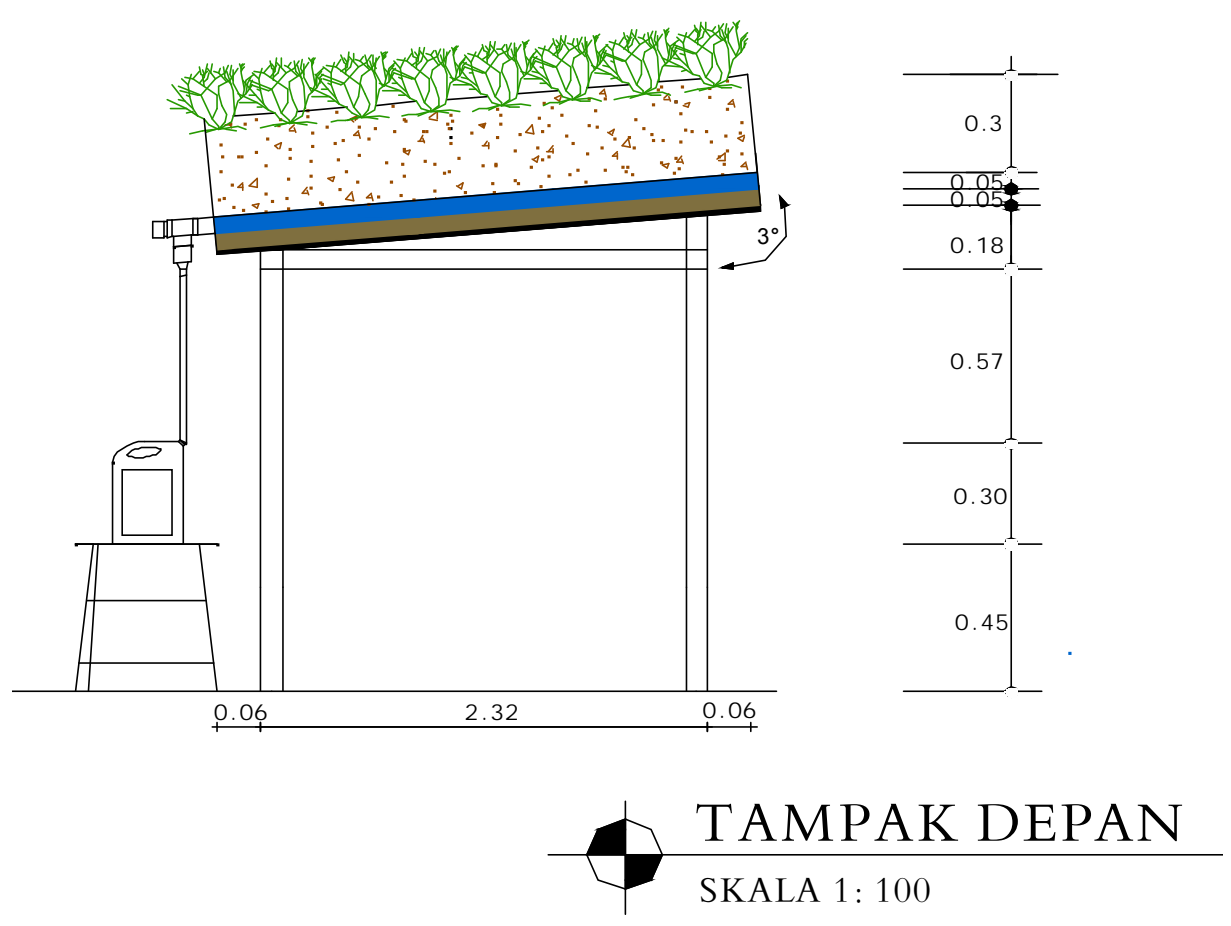

Gambar 2.1 Tampak model green roof

Adapun lapisan dari model green roof yang digunakan pada penelitian ini adalah sebagai berikut:

- Lapisan vegetasi merupakan lapisan teratas dari atap hijau yang yang terdiri dari media tanam. Media tanam yang digunakan dalam penelitian ini adalah tanah dengan ketebalan $30 \mathrm{~cm}$ serta vegetasinya menggunakan Rumput Gajah Mini (Axsonopus.Sp).

- Lapisan selanjutnya adalah lapisan saringan, pada penelitian ini digunakan serat ijuk dengan ketebalan $5 \mathrm{~cm}$.

- Setelah lapisan saringan, dibuat juga lapisan penyaluran air yang terdiri dari batu kerikil yang sudah dicuci, pada penelitian ini batu kerikil yang digunakan dengan ukuran $\varnothing$ 8-16 $\mathrm{mm}$, setebal 5 $\mathrm{cm}$.

- Rangka model green roof menggunakan balok ukuran 6/6, dimana balok tersebut dibuat sesuai dengan ukuran luas penampang multiplek $15 \mathrm{~mm}$.

Metode analisa statistik menggunakan metode anova satu jalur (One Way-Anova) dengan membandingkan nilai antara $F_{\text {hitung }}$ dan $F_{\text {tabel, }}$ dimana perbedaan kedua nilai $F$ tersebut berkaitan dengan hipotesis atau dasar pengambilan keputusan yang dibuat pada penelitian ini sebagai berikut:

$\mathrm{H}_{0}=$ Atap hijau (green roof) tidak berpengaruh pada kualitas air hujan yang melewatinya.

$\mathrm{H}_{1}=$ Atap hijau (green roof) berpengaruh terhadap kualitas air hujan yang melewatinya.

Sehingga hubungan antara nilai $F$ dengan hipotesis pada penelitian ini dinyatakan pada kalimat sebagai berikut :

$$
\begin{aligned}
& \text { lika }-F_{\text {tabel }} \geq F_{\text {hitung }} \text { maka } H_{0} \text { diterima dan } H_{1} \text { ditolak } \\
& \text { lika }-F_{\text {tabel }} \leq F_{\text {hitung }} \text { maka } H_{0} \text { ditolak dan } H_{1} \text { diterima }
\end{aligned}
$$

\section{Hasil dan Pembahasan}

\subsection{Analisa Curah Hujan}

Analisa curah hujan diawali dengan menghitung jumlah curah hujan tahunan dan rata-rata jumlah curah hujan tahunan Kota Pontianak. Berikut data hasil jumlah curah hujan tahunan dan ratarata curah hujan tahunan yang di tunjukkan pada Tabel 3.1. 
Tabel 3.1 Jumlah Curah Hujan dan Rata-Rata Curah Hujan Tahunan

\begin{tabular}{|c|c|}
\hline \multirow{2}{*}{ Tahun } & Jumlah Curah Hujan \\
\hline & Tahunan (mm) \\
\hline 1981 & 3151 \\
\hline 1982 & 2491,7 \\
\hline 1983 & 3403,3 \\
\hline 1984 & 2942,3 \\
\hline 1985 & 2886,5 \\
\hline 1986 & 2604,9 \\
\hline 1987 & 3438,8 \\
\hline 1988 & 3278,9 \\
\hline 1989 & 2906,1 \\
\hline 1990 & 3107,5 \\
\hline 1991 & 2441,4 \\
\hline 1992 & 2787,4 \\
\hline 1993 & 3299,7 \\
\hline 1994 & 2952,1 \\
\hline 1995 & 3019,9 \\
\hline 1996 & 2958,7 \\
\hline 1997 & 2660,6 \\
\hline 1998 & 3874,9 \\
\hline 1999 & 2850,5 \\
\hline 2000 & 3141,6 \\
\hline 2001 & 3149,1 \\
\hline 2002 & 2737,4 \\
\hline 2003 & 3170,5 \\
\hline 2004 & 3294,2 \\
\hline 2005 & 3035,4 \\
\hline 2006 & 2547,3 \\
\hline 2007 & 3663,9 \\
\hline 2008 & 3131,8 \\
\hline 2009 & 3280 \\
\hline 2010 & 3511,6 \\
\hline Rata-rata & 3057,3 \\
\hline
\end{tabular}

Selanjutnya akan dianalisa rata-rata curah hujan 5 tahun bergerak seperti Gambar 3.1 berikut ini.

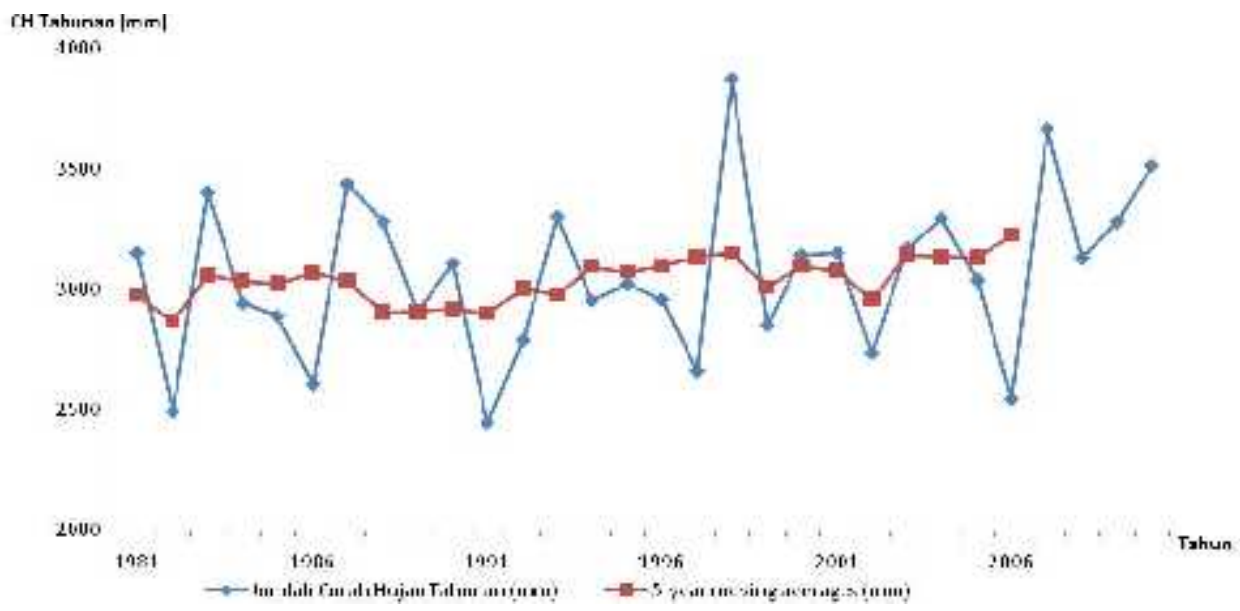

Gambar 3.1 Grafik curah hujan tahunan dan 5-tahun bergerak

Melihat Gambar 3.1, yaitu grafik curah hujan tahunan Kota Pontianak mengalami fluktuasi yang cukup bervariasi. Pada tahun 1991 merupakan jumlah curah hujan minimum, yaitu sebesar 2441,4 $\mathrm{mm}$ dan di tahun 1998 merupakan jumlah curah hujan maksimum, yaitu sebesar 3874,9 mm. Selain itu, dapat dilihat juga rata-rata 5-tahun bergerak yang cenderung meningkat. Selanjutnya dilakukan analisis time trend untuk mengamati pola curah hujan tahunan yang ditampilkan pada Gambar 3.2 di bawah ini. 


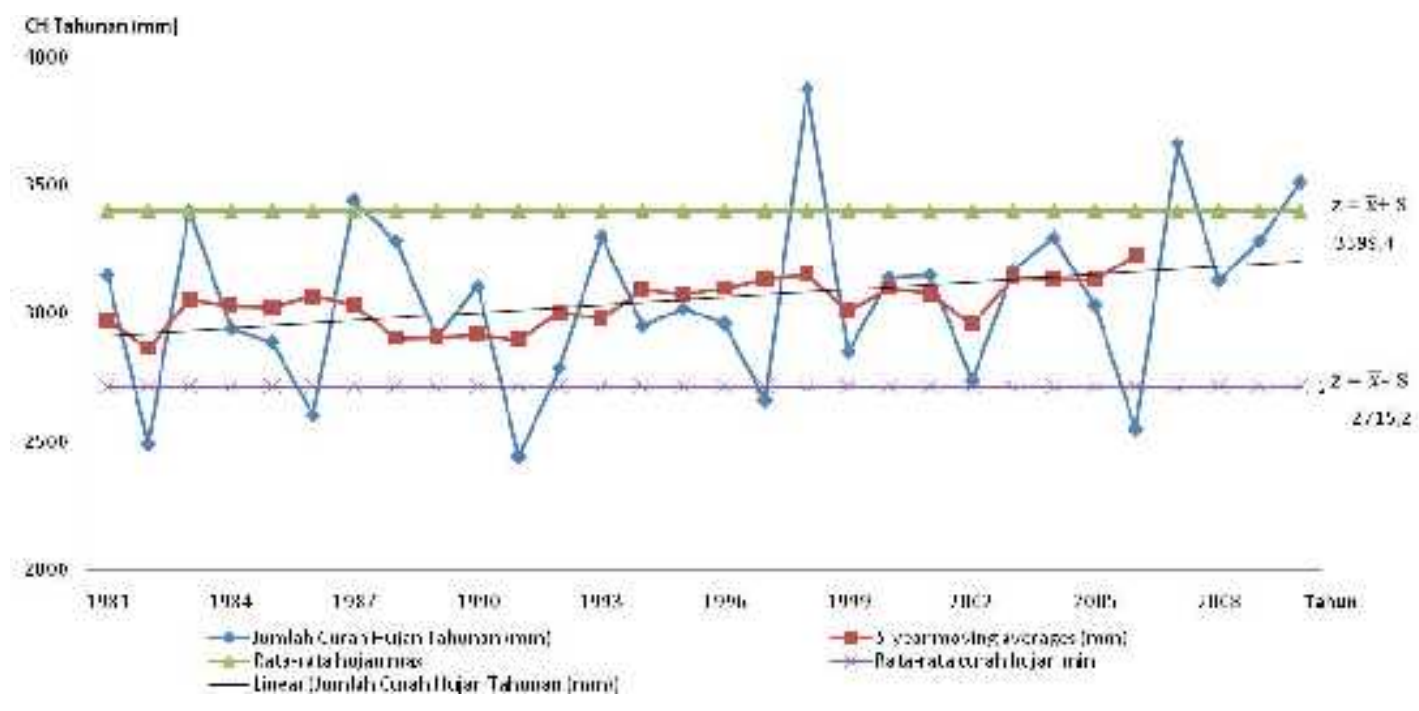

Gambar 3.2 Grafik Jumlah Curah Hujan Tahunan, Jumlah Hujan Rata-Rata Tahunan dan Trend Line

Dari Gambar 3.2 dapat diketahui pola hujan selama 30 tahun, dimana dijelaskan bahwa pola curah hujan tahunan ditunjukkan dengan trend line yang menunjukkan polanya meningkat dan ratarata hujan maksimum sebesar $3399,4 \mathrm{~mm}$ yang disebut juga dengan tahun basah dan rata-rata curah hujan minimum sebesar $2715,2 \mathrm{~mm}$ yaitu tahun kering.

Dapat dilihat juga pola curah hujan dalam setahun sehingga dapat diketahui antara bulan kering dan bulan basah. Seri data yang digunakan untuk mengetahui bulan basah dan bulan kering adalah rata-rata curah hujan tahunan tiap bulan Kota Pontianak tahun 1981-2010. Berikut data bulan kering dan bulan basah yang ditunjukkan pada Tabel 3.2.

Tabel 3.2 Jumlah Curah Hujan Bulanan (Bulan Kering dan Bulan Basah)

\begin{tabular}{ccc}
\hline Bulan & Jumlah curah hujan bulanan $(\mathbf{m m})$ & Keterangan \\
\hline \hline Jan & 306,4 & Normal \\
Feb & 190,9 & Bulan Kering \\
Mar & 254,1 & Normal \\
Apr & 286,8 & Normal \\
Mei & 266,6 & Normal \\
Jun & 198,3 & Normal \\
Jul & 198,8 & Normal \\
Agust & 165,7 & Bulan Kering \\
Sep & 219,3 & Bulan Basah \\
Okt & 330,2 & Bulan Basah \\
Nop & 354,2 & Bulan Basah \\
Des & 285,9 & Normal \\
\hline
\end{tabular}

Melihat data yang diperoleh pada Tabel 3.2, bahwa terdapat beberapa bulan yang mengalami jumlah curah hujan bulanan maksimum dan minimum. Curah hujan bulanan maksimum dapat disebut juga bulan basah yang terjadi pada bulan September, Oktober dan Nopember. Sedangkan bulan kering terjadi pada bulan Februari dan Agustus. Selain bulan yang tergolong pada bulan basah dan bulan kering merupakan normal yang memiliki curah hujan normal. Berdasarkan data tersebut maka pengambilan sampel curah hujan dapat dilakukan pada bulan-bulan basah. Pada penelitian ini pengambilan sampel curah hujan dilakukan pada bulan November.

\subsection{Hasil Pengamatan Sampel Curah Hujan}

Berdasarkan pengamatan langsung terhadap sampel curah hujan diperoleh data-data yang ditampilkan pada Tabel $\mathbf{3 . 3}$ sebagai berikut. 
Tabel 3.3 Pengamatan Langsung Sampel Curah Hujan (Parameter Suhu)

\begin{tabular}{cccc}
\hline Tanggal & T Hujan ke-1 & T Hujan ke-2 & T hujan Lewat Green Roof \\
\hline \hline 24 November 2012 & $\left(27^{0} \mathrm{C}\right)$ & $\left(28^{0} \mathrm{C}\right)$ & $\left(31^{0} \mathrm{C}\right)$ \\
25 November 2012 & $\left(26^{0} \mathrm{C}\right)$ & $\left(26^{0} \mathrm{C}\right)$ & $\left(30^{0} \mathrm{C}\right)$ \\
27 November 2012 & $\left(27^{0} \mathrm{C}\right)$ & $\left(26^{0} \mathrm{C}\right)$ & $\left(30^{0} \mathrm{C}\right)$ \\
02 Desember 2012 & $\left(27^{0} \mathrm{C}\right)$ & $\left(27^{0} \mathrm{C}\right)$ & $\left(30,5^{0} \mathrm{C}\right)$ \\
\hline
\end{tabular}

Dari data di atas dapat dilihat bahwa terjadi perbedaan besar suhu antara air hujan yang melewati green roof dengan yang tidak. Suhu air hujan yang melewati green roof lebih tinggi dibandingkan suhu air yang tidak melewati green roof. Hal ini membuktikan bahwa model green roof yang ditanami dengan tanaman rumput Gajah Mini memberikan pengaruh terhadap kenyamanan termal, dimana tanaman rumput dan lapisan media tanam berperan dalam penyerapan panas dari sinar matahari yang dibuktikan dengan tingginya suhu air hujan yang melewati atap hijau. Tanaman yang terdapat pada atap hijau mempunyai pengaruh yang signifikan dalam pengurangan proses penyerapan panas karena efek bayang-bayang pada siang hari. Efek bayangan dari tanam sangat baik karena tanaman tidak saja mengurangi jumlah panas yang masuk ke dalam bangunan, namun juga turut mendukung hilangnya panas dari bangunan sehingga kenyamanan termal dapat optimal.

Menurut Feriadi dan Frick (2008), atap bertanam berfungsi sebagai penahan yang dapat mengurangi aliran panas (heat flux) yang merambat melalui atap. Lapisan tambahan substrat dan pohon pada atap bertanam dapat menambah nilai penahanan panas/dingin kira-kira sebesar $10 \%$ dari atap biasa.

Selain itu, dari pengamatan langsung terhadap sampel, ditemukan perbedaan warna antara air hujan yang melewati green roof dengan air hujan yang tidak melewati green roof. Berikut gambar yang menunjukkan perbedaan antara air hujan lewat green roof dan tidak lewat green roof yang ditunjukkan pada Gambar 3. 3 di bawah ini.

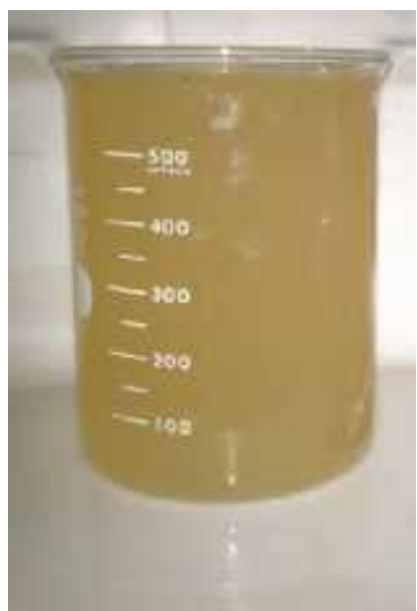

(a)

Melewati green roof

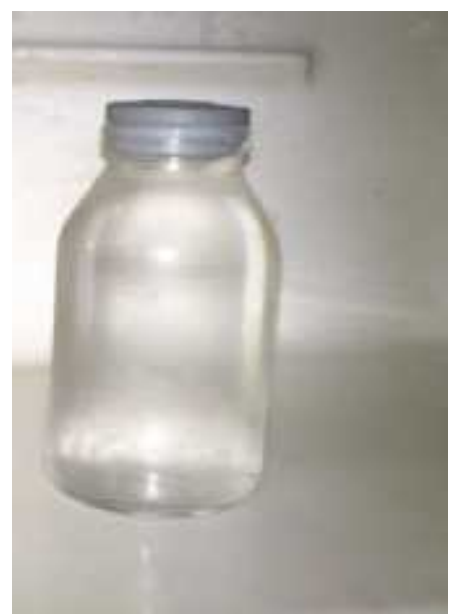

(b)

Tidak melewati green roof

Gambar 3.3 Perbedaan air hujan terhadap warna

Berdasarkan Gambar 3.3 dapat dilihat warna air hujan yang melewati green roof cenderung keruh, hal ini disebabkan karena partikel-partikel halus dari media tanam yaitu tanah terbawa oleh aliran air hujan yang menuju selang pembuangan air. Sedangkan air hujan yang tidak melewati green roof sangat sedikit bahkan tidak ditemukan partikel didalamnya.

\subsection{Analisa Data Statistik}

\subsubsection{Uji Anova Satu Jalur (One Way-Anova)}

Setelah diperoleh hasil uji sampel air hujan dari laboratorium, data tersebut akan diolah dalam perhitungan statistik dengan menggunakan anova satu jalur. Uji anova satu jalur dilakukan pada 
masing-masing parameter yang telah ditetapkan, yaitu $\mathrm{pH}$, kekeruhan, $\mathrm{Pb}$ dan E.Coli. Keluaran dari uji statistik anova satu jalur dalam bentuk tabel-tabel yang memuat tentang besarnya $F_{\text {hitung }}$ dan $F_{\text {tabel }}$ sehingga dapat dilihat apakah perbedaan perlakuan terhadap sampel air hujan signifikan atau tidak. Di bawah ini merupakan hasil uji sampel air hujan yang ditunjukkan pada Tabel 3.4.

Tabel 3.4 Hasil Uji Sampel Air Hujan

\begin{tabular}{|c|c|c|c|c|c|c|c|}
\hline No. & Tanggal & Parameter & $\begin{array}{c}\text { Air Hujan Tidak } \\
\text { Melewati Green Roof } \\
\text { (Pengambilan ke-1) }\end{array}$ & $\begin{array}{c}\text { Air Hujan Tidak } \\
\text { Melewati Green Roof } \\
\text { (Pengambilan ke-2) }\end{array}$ & $\begin{array}{c}\text { Air Hujan } \\
\text { Melewati Green } \\
\text { Roof }\end{array}$ & Metoda & $\begin{array}{l}\text { *)Kadar maksimum } \\
\text { yang diperbolehkan }\end{array}$ \\
\hline \multirow[t]{5}{*}{1} & \multirow[t]{5}{*}{24 Nop'12 } & $\overline{\mathrm{pH}}$ & 5,51 & $\overline{5,5}$ & 6,41 & pH-meter & $6,5-8,5$ \\
\hline & & Kekeruhan (NTU) & 1,23 & 3,88 & 146 & Turbidimeter & 5 \\
\hline & & $\mathrm{Pb}$ Terlarut (mg/l) & 0 & 0,0136 & 0,0271 & AAS & 0,01 \\
\hline & & $\begin{array}{l}\text { Total coliform (Jml } \\
\text { MPN/100 ml) }\end{array}$ & - & - & $\geq 1600$ & WI-M-B-1-ULK (impedance) & 0 \\
\hline & & E Coli Patogen & - & - & - & Biakan & 0 \\
\hline \multirow[t]{5}{*}{2} & \multirow[t]{5}{*}{25 Nop'12 } & $\mathrm{pH}$ & 5,06 & 5,04 & 6,28 & pH-meter & $6,5-8,5$ \\
\hline & & Kekeruhan (NTU) & 1,1 & 1,17 & 226 & Turbidimeter & 5 \\
\hline & & $\mathrm{Pb}$ Terlarut (mg/l) & 0,0339 & 0,0169 & 0,0237 & AAS & 0,01 \\
\hline & & $\begin{array}{l}\text { Total coliform (Jml } \\
\text { MPN/100 ml) }\end{array}$ & - & - & $\geq 1600$ & WI-M-B-1-ULK (impedance) & 0 \\
\hline & & E Coli Patogen & - & - & - & Biakan & 0 \\
\hline \multirow[t]{5}{*}{3} & \multirow[t]{5}{*}{27 Nop'12 } & $\mathrm{pH}$ & 5,34 & 5,25 & 6,36 & pH-meter & $6,5-8,5$ \\
\hline & & Kekeruhan (NTU) & 1,5 & 1,45 & 101 & Turbidimeter & 5 \\
\hline & & $\mathrm{Pb}$ Terlarut (mg/l) & 0,0136 & 0,0237 & 0,0034 & AAS & 0,01 \\
\hline & & $\begin{array}{l}\text { Total coliform (Jml } \\
\text { MPN/100 ml) }\end{array}$ & - & - & $\geq 1600$ & WI-M-B-1-ULK (impedance) & 0 \\
\hline & & E Coli Patogen & - & - & - & Biakan & 0 \\
\hline \multirow[t]{5}{*}{4} & \multirow[t]{5}{*}{2 Des'12 } & $\mathrm{pH}$ & 5,41 & 5,37 & 6,14 & pH-meter & $6,5-8,5$ \\
\hline & & Kekeruhan (NTU) & 1,11 & 0,88 & 126 & Turbidimeter & 5 \\
\hline & & $\mathrm{Pb}$ Terlarut (mg/l) & 0,0102 & 0,0134 & 0,0101 & AAS & 0,01 \\
\hline & & $\begin{array}{l}\text { Total coliform (Jml } \\
\text { MPN/100 ml) }\end{array}$ & - & - & $\geq 1600$ & WI-M-B-1-ULK (impedance) & 0 \\
\hline & & E Coli Patogen & - & - & - & Biakan & 0 \\
\hline
\end{tabular}

*) PERMENKES RI No. 492/Menkes/Per/IV/2010

Dari tabel di atas, dapat dilihat bahwa terdapat 3 kelompok sampel dengan masing-masing parameter. Kelompok yang pertama adalah air hujan tidak melewati green roof (pengambilan ke-1), yang berarti pengambilan sampel pada waktu pertama kali curah hujan turun ke bumi. Kelompok kedua adalah air hujan tidak melewati green roof (pengambilan ke-2), yang berarti pengambilan sampel curah hujan tidak melewati model green roof diambil ketika curah hujan yang jatuh kedalam model dan keluar dari model green roof. Kelompok ketiga adalah air hujan yang melewati model green roof. Melihat data yang diperoleh, bahwa untuk masing-masing kelompok parameter E.Coli negatif atau air sampel tidak mengandung bakteri patogen E.Coli. Sedangkan pada parameter total coliform atau bakteri non-patogen terdapat pada air hujan yang melewati model green roof sebesar $\geq$ 1600 (Jml MPN/100 ml). Pada parameter kekeruhan juga terdapat perbedaan antara 3 kelompok, kelompok pertama mempunyai rentang antara 1,11-1,5 (NTU), kelompok kedua mempunyai rentang antara 0,88-3,88 (NTU) dan kelompok ketiga mempunyai rentang dari 101-226 (NTU). Untuk parameter $\mathrm{pH}$, kelompok pertama mempunyai rentang $\mathrm{pH}$ antara 5,06-5,51. Kelompok kedua mempunyai rentang $\mathrm{pH}$ antara 5,04-5,5 dan kelompok ketiga mempunyai rentang $\mathrm{pH}$ antara 6,146,41 . Sedangkan untuk parameter $\mathrm{Pb}$ terlarut, data yang diperoleh terdapat $\mathrm{Pb}$ terlarut namun sangat kecil.

Dapat juga dilihat data hasil analisa anova satu jalur pada setiap parameter, dimana pada tabel analisa anova ini terdapat 3 sampel. Sampel 1 adalah sampel curah hujan pengambilan ke-1. Sampel 2 adalah sampel curah hujan pengambilan ke-2. Sampel 3 adalah sampel curah hujan lewat model green roof.

Uji anova satu jalur hanya menunjukkan apakah terdapat perbedaan atau tidak dari kelompok yang diuji. Jika hasil uji menunjukkan adanya perbedaan rerata antar kelompok ( $\mathrm{H}_{0}$ ditolak) maka untuk mengetahui dimana letak perbedaan rerata antar kelompok yang diuji harus dilakukan uji lanjutan (post hoc test). Uji lanjutan yang digunakan adalah uji tukey. Uji Tukey (HSD=Honest Significantly Difference) juga disebut BNJ (Beda Nyata Jujur). Digunakan uji tukey, karena ketiga 
sampel dengan asumsi homogenitas varian terpenuhi dan jumlah $n$ setiap variabel sama. Di bawah ini merupakan tabel hasil analisa anova satu jalur dan tabel hasil uji lanjutan Tukey HSD pada parameter $\mathrm{pH}$, kekeruhan dan $\mathrm{Pb}$ terlarut.

Di bawah ini merupakan tabel ringkasan analisa dengan anova satu jalur pada setiap parameter yang ditunjukkan pada Tabel $\mathbf{3 . 5}$ dan tabel hasil uji lanjutan Tukey HSD yang dapat dilihat pada pada Tabel 3.6.

Tabel 3.5 Anova Satu Jalur pada Setiap Parameter

\begin{tabular}{|l|c|}
\hline \multicolumn{1}{|c|}{ Parameter } & $\mathbf{F}_{\text {hitung }}$ \\
\hline $\mathrm{pH}$ & $43,705^{* *}$ \\
\hline Kekeruhan & $30,041^{* *}$ \\
\hline Timbal & $0,054^{\text {ns }}$ \\
\hline \multicolumn{2}{|c|}{} \\
\hline
\end{tabular}

Ket.: notasi $\left({ }^{*}\right)$, memberikan pengaruh signifikan

notasi $\left({ }^{\text {ns }}\right)$, tidak memberikan pengaruh signifikan.

Tabel 3.6 Hasil Uji Lanjutan Tukey HSD

\begin{tabular}{|l|l|l|}
\hline \multicolumn{1}{|c|}{ Sampel } & \multicolumn{1}{c|}{ pH } & \multicolumn{1}{c|}{ kekeruhan } \\
\hline Sampel 1 & $5,2900^{\mathrm{a}}$ & $1,2350^{\mathrm{a}}$ \\
\hline Sampel 2 & $5,3300^{\mathrm{a}}$ & $1,8450^{\mathrm{a}}$ \\
\hline Sampel 3 & $6,2975^{\mathrm{b}}$ & $149,7500^{\mathrm{b}}$ \\
\hline
\end{tabular}

Ket.: notasi $\left({ }^{b}\right)$, terdapat perbedaan.

Dari hasil analisa di atas, dapat dilihat bahwa untuk parameter $\mathrm{pH}$ dan kekeruhan terdapat perbedaan yang signifikan. Perbedaan tersebut dapat dilihat dari besarnya $F_{\text {hitung }}$ yang diperoleh. Besar $F_{\text {hitung }}$ untuk parameter $\mathrm{pH}$ dan kekeruhan adalah sebesar 43,75 dan 30,041, sedangkan besarnya $F_{\text {tabel }}$ adalah 4,26 yang diperoleh dari Tabel $F$ dengan kelompok (pembanding) $=2$ dan kelompok (penyebut) $=9$, pada alfa $=0,05$. Setelah dibandingkan antara $F_{\text {hitung }}$ dengan $F_{\text {tabel }}$ maka, $F_{\text {hitung }}>F_{\text {tabel }}$ (terdapat perbedaan signifikan). Pada perameter $\mathrm{Pb}$ terlarut nilai $\mathrm{F}_{\text {hitung }}$ lebih kecil daripada $F_{\text {tabel }}$ yaitu, $(0,947<4,26)$, sehingga tidak terdapat perbedaan signifikan.

Perbedaan signifikan terdapat pada parameter $\mathrm{pH}$ dan kekeruhan sehingga dapat dilihat tabel hasil uji lanjutan Tukey HSD, dimana pada masing-masing parameter perbedaan terdapat pada sampel 3 yaitu sampel air hujan yang melewati green roof. Perbedaan signifikan parameter $\mathrm{pH}$ terdapat pada sampel 3 dengan rata-rata sebesar 6,2975 dan jika dibandingkan dengan standar baku mutu untuk air bersih berdasarkan pada PERMENKES RI No. 492/Menkes/Per/IV/2010, air hujan yang melewati green roof mendekati pada standar tersebut. Faktor yang menyebabkan perbedaan besarnya $\mathrm{pH}$ antara air hujan yang lewat green roof dengan yang tidak, dikarenakan air hujan yang melewati green roof mengalami kontak dengan lapisan green roof itu sendiri. Salah satu lapisan yang dilewati oleh air hujan tersebut adalah lapisan media (tanah). Karakteristik tanah salah satunya adalah pH. Jika pH suatu tanah asam, maka air yang melewatinya akan menjadi turun atau asam dan jika pH suatu tanah basa, maka $\mathrm{pH}$ air tersebut akan naik yang dapat mendekati netral atau basa. Perbedaan signifikan juga terjadi pada parameter kekeruhan dengan rata-rata 149,75 NTU, namun Jika ditinjau dengan Permenkes tahun 2010, kekeruhan pada sampel 1 dan 2 memenuhi standar, dimana besarnya kekeruhan yang diperbolehkan adalah sebesar 5 NTU. Sedangkan untuk kekeruhan sampel 3, tidak memenuhi standar karena besarnya kekeruhan sangat tinggi sehingga tidak diperbolehkan untuk keperluan air bersih. Pada parameter $\mathrm{Pb}$ terlarut tidak terdapat perbedaan signifikan antara ketiga sampel. Hal ini menunjukkan bahwa, atap hijau tidak memberikan pengaruh terhadap air hujan yang melewatinya dan sama dengan hasil air hujan yang tidak melewati green roof. Besarnya Pb terlarut yang diperoleh dari hasil uji laboratorium adalah antara 0-0,0339 $\mathrm{mg} / \mathrm{l}$. Sesuai dengan Permenkes tahun 2010 besar kandungan timbal dalam air bersih adalah sebesar $0,01 \mathrm{mg} / \mathrm{l}$ dan melihat data yang diperoleh bahwa terdapat sampel air hujan yang mengandung $\mathrm{Pb}$ terlarut di atas ambang batas yang diperbolehkan yaitu pada air hujan pengambilan ke-1 sebesar $0,0339 \mathrm{mg} / \mathrm{l}$. 
Dari hasil analisa laboratorium terhadap sampel air hujan lewat green roof yang dilakukan, diperoleh bahwa identifikasi terhadap bakteri $E$. coli negatif. Hal ini menunjukkan bahwa, air yang melewati atap hijau tidak mengandung bakteri patogen yaitu E.coli. Sehingga dapat dikatakan air hujan masih tergolong aman digunakan untuk kebutuhan sehari-hari. Sama halnya, keberadaan E.coli pada air hujan yang langsung ditampung sudah dipastikan negatif. Berdasarkan penelitian yang pernah dilakukan oleh Susianah, T dan A. Masduqi (2010) menyatakan bahwa air hujan tidak mengandung bakteri E.coli, kecuali bakteri total coliform yang dapat dihilangkan dengan merebus air hujan tersebut. Sehingga analisa air hujan yang langsung ditampung (ambient sample) tidak perlu dilakukan pada penelitian ini.

Berdasarkan hasil analisa statistika yang telah dilakukan dapat dilihat bahwa, pengaruh atap hijau dengan model yang mengacu pada (Feriadi dan Frick, 2008) mempunyai pengaruh terhadap kualitas air hujan yang melewatinya pada parameter $\mathrm{pH}$ dan kekeruhan, tetapi tidak pada parameter $\mathrm{Pb}$ terlarut dan bakteri E.Coli. Rangkuman pengaruh atap hijau terhadap masing-masing parameter selengkapnya dapat dilihat pada Tabel 3.7.

Tabel 3.7 Rangkuman Pengaruh Atap Hijau Terhadap Parameter Uji

\begin{tabular}{clccc}
\hline \multirow{2}{*}{ NO. } & \multirow{2}{*}{ Parameter } & \multicolumn{2}{c}{ Model Atap Hijau } & \multirow{2}{*}{ Keterangan } \\
\cline { 2 - 3 } & & Berpengaruh & Tidak Berpengaruh & \\
\hline \hline 1 & pH & $\checkmark$ & & Signifikan \\
2 & Kekeruhan & $\checkmark$ & & Signifikan \\
3 & Pb terlarut & & $\checkmark$ & Tidak Signifikan \\
4 & Bakteri E.coli & & $\mathrm{V}$ & Tidak Ditemukan \\
\hline Ket.: & Taraf signifikan $=0,05$ & &
\end{tabular}

Ket.: Taraf signifikan $=0,05$

Dari Tabel 3.7 dapat dilihat bahwa atap hijau berpengaruh pada pH dan kekeruhan, sedangkan pada $\mathrm{Pb}$ terlarut dan bakteri E.Coli atap hijau tidak berpengaruh. Pengaruh model atap hijau terhadap air hujan yang telah melewatinya pada parameter $\mathrm{pH}$ memberikan pengaruh yang baik jika dibandingkan dengan air hujan yang tidak melewati atap hijau. Seperti yang telah dijelaskan sebelumnya $\mathrm{pH}$ air hujan yang melewati model atap hijau lebih baik dan sesuai dengan Permenkes nomor 492 Tahun 2010.

Pada parameter kekeruhan, model atap hijau pada penelitian ini memberikan pengaruh yang buruk terhadap air hujan yang melewati model tersebut. Hal ini dikarenakan pengaruh dari intensitas hujan yang cukup kuat (hujan lebat) yang mengakibatkan butiran tanah pada media tanam lepas dan hanyut terbawa air hujan menuju saluran air yang telah dibuat pada model atap hijau (model atap hijau selengkapnya dapat dilihat pada lampiran F). Rata-rata besar kekeruhan pada air hujan yang melewati atap hijau sebesar 149,7500 NTU. Besarnya kekeruhan yang terjadi juga dipengaruhi oleh butiran tanah yang terbawa pada hujan sebelumnya saat pengambilan sampel. Berdasarkan hasil tersebut maka besarnya kekeruhan dari air hujan yang melewati atap hijau melampaui standar baku mutu air minum pada Permenkes no. 492 Tahun 2010, yaitu sebesar 5 NTU. Sedangkan untuk parameter $\mathrm{Pb}$ terlarut, atap hijau tidak memberikan pengaruh apapun. Hal ini dapat dilihat pada analisa data dengan uji anova yang telah dijelaskan sebelumnya.

Dari analisa laboratorium untuk paramter bakteri E.Coli telah dilakukan identifikasi dan hasilnya negatif terhadap air hujan yang melewati green roof maupun yang tidak. Atap hijau (green roof) berpengaruh terhadap kualitas air hujan di Kota Pontianak pada parameter pH dan kekeruhan. Namun pada parameter kekeruhan, atap hijau memberikan pengaruh yang buruk dimana tingginya nilai kekeruhan yang disebabkan oleh pengaruh media tanam yang digunakan dalam penelitian ini yaitu tanah. Adapun untuk mengurangi tingginya tingkat kekeruhan air hujan yang melewati atap hijau, media tanam dapat ditambahkan dengan sabut kelapa. Berdasarkan penelitian yang telah dilakukan oleh Sudarmanto (1987), dijelaskan bahwa media tanam untuk taman atap dapat menggunakan media tanam yang terdiri dari tanah dan sabut kelapa, dimana selain dapat mengurangi tingkat kekeruhan yang terjadi karena partikel tanah tertahan oleh sabut kelapa, bobotnya juga relatif lebih ringan daripada media tanam hanya dari tanah. Selain dengan penambahan media tanam, kekeruhan juga dapat diatasi dengan pemasangan karbon aktif pada 
bagian pipa saluran airnya. Karbon aktif atau sering dikenal dengan arang aktif merupakan salah satu media filter yang sering digunakan oleh masyarakat umum, selain harganya murah, arang aktif sangat mudah untuk didapatkan di pasaran. Dari seluruh analisa kualitas air hujan melewati green roof terhadap parameter yang diuji, dapat disimpulkan bahwa atap hijau mempunyai pengaruh terhadap kualitas air hujan dan atap hijau yang digunakan pada penelitian ini belum memenuhi syarat sebagai media filter air hujan di Kota Pontianak.

\section{Kesimpulan}

Dari penelitian yang telah dilaksanakan maka dapat disimpulkan ;

1. Berdasarkan uji stastistik dengan anova satu jalur, diketahui bahwa terdapat perbedaan signifikan antara air hujan yang melewati green roof dengan yang tidak melewati green roof pada beberapa parameter uji, yaitu parameter $\mathrm{pH}$ dan kekeruhan, namun pada parameter $\mathrm{Pb}$ terlarut tidak terdapat perbedaan yang signifikan.

2. Berdasarkan hasil analisa laboratorium, diketahui bahwa tidak ditemukannya keberadaan bakteri patogen (E.Coli) pada sampel air yang diambil atau dengan kata lain, bakteri E.Coli tidak teridentifikasi dalam sampel air hujan yang diambil.

3. Berdasarkan hasil dari penelitian ini, model atap hijau yang digunakan memberikan pengaruh terhadap air hujan di Kota Pontianak namun, belum dapat berfungsi sebagai filter air hujan di Kota Pontianak dikarenakan model yang digunakan hanya satu model green roof dengan lapisan media tanam tanah yang berpengaruh pada tingginya tingkat kekeruhan.

\section{Ucapan Terima Kasih}

Penulis mengucapkan terima kasih kepada kedua orang tua yang telah memberi dukungan secara moril maupun materil. Penulis juga mengucapkan terima kasih kepada Bapak Kiki Prio Utomo, ST, M. Sc. dan Bapak Agus Rulyansyah, SP, M. Si., selaku dosen pembimbing dalam penelitian ini. Tidak lupa juga kepada teman-teman angkatan 2008 (SEBVYRUS) Fakultas Teknik UNTAN.

\section{Referensi}

Arisanti, A. 2005. Adaptasi Anatomis Pohon Roof Garden (Studi Kasus : Kondominium Taman Anggrek, Jakarta). Bogor.

Ferdiadi, H dan F. Heinz. 2008. Atap Bertanam Ekologis dan Fungsional. Yogyakarta: Kanisius.

Sudarmanto. 1987. Pengaruh Berbagai Media Ringan untuk Taman Atap (Roof Garden) Terhadap Pertumbuhan Beberapa Jenis Tanaman Penutup Tanah (Ground Cover). Bogor: Institut Pertanian Bogor.

Susianah, T dan A. Masduqi. 2010. Air Hujan Sebagai Alternatif Pemenuhan Kebutuhan Air Minum Di Kecamatan Ranuyoso Kabupaten Lumajang. Surabaya: ITS Press. 